\title{
EXPLORING THE SOCIAL CONSTRUCTION OF LIFE ROLES OF CAREER-ORIENTED WOMEN
}

\author{
KIM FRANKS \\ WILLEM SCHURINK \\ LINDA FOURIE \\ Department of Human Resource Management \\ University of Johannesburg
}

\begin{abstract}
The ever-growing number of women in the contemporary workforce is presenting numerous challenges to organisations, employees and their families. The aim of this study was therefore twofold, namely, to explore how 21 st century careeroriented women attach meaning to their different life roles, as well as how they visualise integrating these over the next decade. A modernist qualitative methodology and grounded theory were applied. Rich, interesting data was obtained from which four themes were inferred implying career-oriented women still placing importance on the traditional mother role. The article concludes with indicating key implications of the findings and recommendations.
\end{abstract}

\section{OPSOMMING}

Die steeds groeiende aantal vroue in die kontemporêre arbeidsmag bring enorme uitdagings vir organisasies, werknemers en hul gesinne mee. Die doel van hierdie studie was derhalwe tweeledig: om te verken hoe 21eeuse beroepsgeoriënteerde vroue betekenis aan hul onderskeie lewensrolle gee, asook hoe hulle visualiseer om hierdie rolle gedurende die komende dekade te integreer. 'n Modernisties kwalitatiewe metodologie en begronde teorie is aangewend. Ryk en interessante data is verkry waaruit vier temas afgelei is wat impliseer dat beroepsgeoriënteerde vroue die tradisionele moederrol steeds belangrik ag. Die sleutelimplikasies van die bevindinge asook aanbevelings sluit die artikel af.

It is expected that in years to come the female labour force in South Africa will grow faster than its counterpart. For example, Muchinsky, Kriek and Schreuder (1998) predict that the average growth rate per year to 2011 will be 3,2\% for women and only $2,4 \%$ for men. Young women, in particular, are becoming more career-oriented, with high educational aspirations and greater extrinsic ambitions (Dennehey \& Mortimer; Marini, Fan, Finley \& Beutel in Johnson and Mortimer, 2000). However, at the same time, young women are still maintaining the value traditionally placed on family and nurturing roles (Johnson \& Mortimer, 2000). Following this, the need to find a way to best invest in work and family life has become more intense in recent years.

The phrase "work-family" emerged in the 1980's, a time when married women's labour force participation experienced a steep increase and when the spheres of work and family were more clearly separated than they are today (Barnett, 1999). Han and Moen (1999) point out that a broader understanding of the complexity of workfamily life paths is particularly crucial given the fundamental changes in the world of work. Traditional gender stereotypes suggested that women's primary social roles were wife and mother, whereas those of men were breadwinner. However, as pointed out by Gottlieb, Kelloway and Barham (1998) by treating family matters as categorically inappropriate intrusions in the workplace, employers helped maintain the sharp psychological separation of these two spheres ${ }^{1}$. This state of affairs, together with the recent influx of women into the labour force, has led to additional challenges confronting women who have to integrate and invest in a variety of different life roles as well as to employers having to address job dissatisfaction, low morale, absenteeism and turnover.

Important in this context is Kruger's (1999) concept of life role. Life role refers to a place in society, together with a defined set of code of conduct, and attitudes, deemed appropriate for people occupying such roles. She (Kruger, 1999) adds that roles represent responsibilities, relationships and areas of contribution. In past centuries, the biological fact of maternity shaped the traditional roles of the sexes. Women performed the home-centred functions that related to the bearing and nurturing of children while men did the work that required great physical strength. Today in the developed world, the only role remaining uniquely gender related is childbearing. Yet men and women are still socialised to perform their traditional roles ${ }^{2}$.

Amongst the multiple life roles that present day women perform, the most common one is clearly that of mother. Therefore it should come as no surprise that many working women like to, if not have to, rely on social support to assist them with their childcare responsibilities However, as Reskin and Padavic (1994) correctly state, women's increasing participation in the paid workforce has reduced the number of relatives available for childcare substantially. This, in turn, has resulted in women attempting to deal with childcare demands either by relying on organised child-care facilities or undergoing changes in their personal employment style, such as working from home or working part-time. In addition to bearing the responsibility of providing adequate childcare to their children, women may also experience feelings of guilt if they do not at least devote some of their free time to this task. Some women may therefore reduce their amount of sleep or free time resulting in the accumulation of strain and stress.

Care of elderly or sick relatives is another family demand working women increasingly face. As the number of the elderly increases, a growing number of workers must somehow fit caretaking into their days by forgoing sleep, leisure, and in some cases full-time employment.

A further major problem for women who attempt to integrate multiple life roles is finding time for both housework and paid work. Many men and women believe that working couples should share household responsibilities. Yet working women today are still maintaining the responsibility of household demands as housework remains being associated with women's 
work. This increased workload makes it difficult for women to wind down which, in turn, may threaten their physical and mental health ${ }^{3}$.

Part of a married couple's obligations is contributing to each other's personal growth, and feelings of belonging and bonding. This includes providing love, support and commitment to the partner, in addition to physical and spiritual aspects of a relationship. Therefore it is conceivable that a working woman playing the role of wife is subjected to a number of potentially stressful conditions 4 .

In addition to the above-mentioned roles of working women, there are other life roles they may occupy simultaneously which need to be taken into consideration. For example, a woman may play the role of a daughter, sister and community member. Kruger (1999) identified four categories of common life roles, namely, personal roles, professional roles, recreational roles, and citizen roles. Each category contains a number of different roles that can exist simultaneously in a person's life. For example, an individual can be a parent, doctor, tennis player and community member at the same time. Fulfilling one or more of these roles has far reaching consequences ${ }^{5}$.

Nelson and Burke (2002) argue that women are prone to role overload, which is the experience of multiple, conflicting expectations from others. This higher incidence of the experience of role conflict, stress and overload can be attributed to the competing demands made by a woman's different role obligations with regard to her limited resources with reference to time, energy and emotional commitment. This dilemma can become even more problematic in cases where one or both the spouses are involved in occupations in which they are expected to be highly committed, not only to their jobs per se, but also to the organisation. In today's fast-paced and highly competitive world, employers expect their employees to go above and beyond a typical job description. Among the demands made by many employers are long working hours, periodic geographical separation from the family and a constant preoccupation with work-related issues.

Aaron-Corbin (1999) states that the more positions a person acquires and the more roles he or she is expected to engage in, the more complex it becomes to meet the responsibility of each role. This form of conflict has taken on new significance in the past decade and has important implications in predicting an individual's longevity in a company; especially for young women who are preparing for the challenges they anticipate in combining marriage, a career and other life roles.

In light of the discussion in the preceding paragraphs, a major problem women thus face today is managing their time efficiently so as to fulfil both their age-old, stereotypical obligations as homemakers and their newer obligations as paid workers. According to Naidoo and Jano (2002), this work and home interface creates much conflict for the dual-career woman because of the different role expectations and demands on her time. Dualcareer women do not have time to perform the tasks of the different roles incumbent on them resulting in a compromise of some degree in one or more roles (Naidoo \& Jano, 2002). This in turn, tends to have an impact on either their work or family life.

In the discussion thus far we have generally attended to the work and home interface globally. We now supplement the discussion with an overview of this study area in the local context.
Not different to the situation abroad, the increase in the number of women in the workforce is clearly evident in South Africa. In a study conducted by Brink and De la Rey (2001), it was noted that out of 40000 South African entrepreneurs who have received loans from the Small Business Development Corporation since its founding in 1981, about $25 \%$ have been women (Neft \& Levine in Brink \& De la Rey, 2001). In addition, the October 1995 household survey found that of the overall number of managers in South Africa, 22\% were women. In comparison the percentage of managers who were women were estimated at $40 \%$ in the United States of America and between $20 \%$ and $30 \%$ in Europe (Guyon in Brink \& De la Rey, 2001). This evidence suggests that a rising number of career-oriented women are not only entering the workforce but are also high-powered, and therefore stressful and demanding local occupations. Similarly, working women in South Africa also experience conflict resulting from their attempts to integrate multiple roles. Results of the abovementioned study imply that women participants generally had accepted that they are responsible primarily for organising their lives in ways that enable them to combine work and family responsibilities. In addition, the majority of participants indicated that their husbands supported the 'idea' of their working and that they participated in domestic and childcare duties; however, husband support did not necessarily translate into an equal sharing of domestic and childcare chores (Brink \& De la Rey, 2001).

Collins (1996) states that, with regards to studies of role salience, even though cultural differences have been noted in the salience given to various life roles, the results of South African research generally tends to reflect the same trends as similar research carried out in other countries. Similar trends include those cited by Langley in Collins (1996), such as the tendency of young females to score highly on commitment to the worker role, as well as on scales with regards to the study, community and home and family roles, while males scored highly on leisure as well as participation in the worker role.

In comparison to the point made above about a woman's role of wife or partner, findings of a study conducted by Theunissen, Van Vuuren and Visser (2003) indicated that male partners experienced more conflict than their female partners if they do not have adequate information regarding their female partners' jobs. This finding suggests that women have an important obligation to provide their partners with regular job-related information in order to reduce the work-family conflict experienced by their partners. Smit (2001) is of the opinion that if both dual-earner spouses are not committed to growth in their marriage, the experience of a high-level of marital integration and happiness will not be possible.

While important work, theoretically and empirically, has been done by South African authors but especially scholars abroad, many questions and phenomena remain unexplored. We conclude this introductory part by highlighting areas we view particularly prominent at this point in our country.

Because of the high cost of living in our country, as well as increased work opportunities due to employment equity policies, South African women are clearly encouraged to enter the labour market. While they have been entering the labour market pretty rapidly, South African women appear at the same time to maintain, if not increase placing importance on the family domain. Not unexpectedly, this has increasingly created stress associated with investing time, energy and resources into multiple life roles. In addition, the

3 There are studies that show that levels of stress hormones, such as epinephrine, norephinephrine, and cortisol remain high after work hours especially for women, which can lead to feelings of fatigue and eventually to ill health (Lundbers \& Frankenhaeuser in Nelson \& Burke, 2002). 4 According to Greenhaus, Callanan and Godshalk (2000), a dual-career relationship faces extensive work-family conflict, gender identity problems, competition and jealousy between partners, negotiation of career priorities, and the possibility of somewhat limited or slow career progress.

5 Some researchers (Ruderman, Ohlott, Panzer \& King, 2002; Sharma, 1999; Waldron, Weiss \& Hughes, 1998) have reported that the roles women play in their lives provide psychological benefits, emotional advice and support, practice at multi-tasking, and opportunities to enrich interpersonal skills. Research results of Ruderman et al. (2002) indicated that multiple role commitment is positively related to life satisfaction, self-esteem and self-acceptance. Krause (2003), however, states that notwithstanding the benefits of having several major life roles, a substantial amount of evidence suggests that the conflict experienced due to balancing multiple roles, particularly those involved within the work an family domains contributes to negative psychological and physical well being of individuals. According to her (Krause 2003), global well-being, increased family distress and depression, increased physical ailments, job and family dissatisfaction, work and family tension, impaired marital functioning and lower life satisfaction highlight only a small portion of the available findings which reflect the negative influence of work-family conflict. Thus, the consequences,
being both psychological and monetary, will affect individuals, their families, and organisations. In addition, Lindsey (1997) argues that the impact of the employed wife assuming multiple life roles, for example, carrying the load for household and child-care responsibilities, has negative consequences for her career success. A high degree of commitment and personal sacrifice is associated with career orientation along with the assumption that a developmental sequence will characterise one's career path. Lindsey (1997) suggests that women who have careers but still take on the bulk of the household labour find it difficult to achieve beyond a certain level. According to Aaron-Corbin (1999), marriage an family are assets for men, but can be considered a career inhibitor for women. Similarly, Rothbard and Edwards (2003) reported that increasing the amount of time invested in family was related to reducing the amount of time investe in work for women but not for men. 
nature of our diverse nation implies that we need to understand how different groups of women in the Rainbow nation assign meaning to their life roles and how they anticipate integrating these roles.

While some work has been done in the field of multiple role conflict, especially into how women in managerial positions integrate their multiple roles (e.g. Naidoo \& Jano, 2002) in South Africa, more in-depth qualitative work involving women themselves, who are currently career-focused and engaged in full time work, are needed so that first hand data as to how they experience and attach meaning to their different life roles and manage them in their everyday life situation can be obtained. Such an "insider" perspective into the lives of these women could not only assist themselves to manage and integrate their various life roles successfully and to reap the benefits associated with occupying different roles, but such data if carefully and scientifically collected would also contribute in our knowledge in this area by establishing building blocks. In addition, such information may inform appropriate organisational policies regarding childcare and working hours, to satisfy the needs of these women as well as assisting local employers to employ women resulting in fewer problems like absenteeism, tardiness, turnover, and unproductive employees.

In conclusion: it is particularly important to explore the topic of the work-family domain further in South Africa. Not only will insight into the social worlds of women, and particularly the meanings they attach to their life roles increase our understanding thereof, but it may contribute to making local women groups generally more aware of how women construct life roles, thereby generally increasing their self-awareness, as well as how to manage the challenges they face in integrating these roles. In addition, such knowledge should assist industrial psychologists and other social service providers in assisting women in enhancing their quality of life as well as improving productivity and satisfaction in the workplace.

In light of the preceding we decided to explore and describe the experiences and views of a small group of local women of their life roles as well as how they anticipate managing these over the next decade. A particular objective of ours was establishing whether these career-oriented women wish to allow their careers to take a back seat to their traditional role of caring for children and in this way ascertain if South African expectations of women, i.e. to play a prominent mother and homemaker role, still prevail amongst career-oriented women.

\section{RESEARCH DESIGN}

\section{Research approach}

Locke (2001) argues that there is currently much depth and complexity of both traditional and applied qualitative research perspectives into which a socially situated researcher enters. These traditions locate the researcher in history, simultaneously guiding and constraining work that will be done in any specific study. It is therefore important that the researcher from the outset to the best of his/her ability "unpack" his or her scientific beliefs.

Assuming a relativist ontology ${ }^{6}$ i.e., presuming that multiple realities are constructed by people as they go about life, and epistemologically believing that we need to apply appropriate research methods to capture the richness of people's social worlds, in order to ultimately understand or appreciate it, we chose a qualitative methodology. After carefully studying the acknowledged approaches of qualitative research traditions in the field which would be most suitable to accomplish the study's aims, we opted for what has become known as the modernist tradition of qualitative research ${ }^{7}$. In line with the modernist tradition is the theoretical tradition in sociology known as symbolic interactionism, which rests on three premises, namely (i) humans act toward things based on the meanings those things have for them, (ii) meanings of things arise out of social interaction, and (iii) meanings are created and changed through a process of interpretation (Esterberg 2002) ${ }^{8}$.

\section{Participants}

Glaser in Locke (2001) states that as researchers begin a study they select particular individuals, groups, and/or settings they believe will provide rich information on the research topic. In selecting people as research participants who were exposed to the subject of the study, Franks chose purposive sampling 9 which, according to Kerlinger and Lee (2000), is characterised by the use of judgement and a deliberate effort to obtain representative samples by including presumably typical areas or groups. In order to gain entree into the field Franks approached women she personally knew that fitted the profile required and asked them if they would participate in the study. This led to one research participant being recruited through snowball sampling, i.e. Franks asked one of the research participants to put her in contact with someone she knew who belongs to the required group. Finally, Franks employed theoretical sampling at least to some extent. According to Locke (2001), the rationale for this form of sampling is to direct all data gathering efforts towards gathering information that will best support the development of the developing theoretical concept. She (Locke, 2001) further states that the logic of theoretical sampling calls upon researchers to flexibly pursue data collection to support category development to the point of theoretical saturation and the attending development of the conceptual scheme until it stabilises. Franks therefore sought information and comparative data after each interview to illuminate the emerging construct.

The research participants were firstly, individual women who have at least a Bachelor's degree demonstrating an ambition to belong to the working class. Secondly, they had worked for at least two years ensuring their experience of being employees. Thirdly, they were between 23 and 28 years representing women usually considered young, having completed their degrees and having at least two years working experience. Fourthly, the research participants were neither married nor ever having been married. This was in line with the aim to include young women with experiences and views of multiple life roles, albeit not being restricted to wife and/or mother roles. Fifthly, the interviewees were white women. Franks decided not to include their counterparts who had previously disadvantaged backgrounds since she anticipated that culturally their experiences and perspectives would be varied. Finally, the women may be considered upper class who have resources to secure childcare and domestic workers, and to take part in multiple life roles including, for example, belonging to a sports club. In the end Franks managed to interview ten research participants.

Table 1 provides a summary of the profiles of the research participants at the time of data gathering, indicating homogeneity as well as heterogeneity.

6 "Questions of social ontology are concerned with the nature of social entities. The central point of orientation here is the question of whether social entities can and should be considered objective entities that have a reality external to social actors, or whether they can and should be considered social constructions built up from the perceptions and actions of social actors. These positions are frequently referred to respectively as objectivism and constructivism. (Bryman, 2004) (Emphasis in the original). 7 The modernist moment, coined by Denzin and Lincoln (2003), resembles the second developmental phase of qualitative research, which extended through the post-war years, the 1970's, the mid-1980's and to the work of many contemporary qualitative scholars, has generated pretty influential "formalised" methods. Schurink (2003) points out that this tradition is characterised by the interpretation of social reality by means of formalised methods of data collection and rigorous tools of data analysis (e.g. analytical induction and grounded theory). According to him (Schurink, 2003), examples of this tradition include the symbolic interactionist
perspective as reflected in well-known textbooks and works of Bogdan and Biklen (1998 \& 2003), Bogdan and Taylor (1975), Taylor and Bogdan (1998), Glaser and Strauss (1967), Lofland (1971), and Lofland and Lofland (1995), to mention but a few. 8 The definition of the concept of life roles provided by Kruger (1999) which has already been referred to is generally in line with those within this paradigm; roles are perceptions shaped by society and provide people with meaning. Every person has different life roles and assigns different meanings to these. Thus, this approach is appropriate for exploring meanings that young women assign to their life roles. Furthermore, society traditionally expects women to conform to the wife, mother and homemaker roles. In short, since such expectations in society are socially constructed the paradigm is particularly appropriate. 9 Purposive sampling forms part of non-probability sampling, which does not make use of random sampling. Studies can be replicated with different samples if non-probability sampling is used, however, probability sampling, which uses some form of random sampling, is advantageous because each member of the population has an equal chance of being selected for the sample (Kerlinger \& Lee, 2000). However, for the purpose of this study, non-probability sampling would be most appropriate. 
TABLE 1

Profiles OF ReSEARCh PARTICIPANTS

\begin{tabular}{|c|c|c|c|c|c|c|c|c|c|}
\hline & $\begin{array}{l}\text { No. of } \\
\text { years work } \\
\text { experience }\end{array}$ & $\begin{array}{l}\text { Qualification at time of data } \\
\text { gathering }\end{array}$ & Race & $\begin{array}{l}\text { Age at time } \\
\text { of data } \\
\text { gathering }\end{array}$ & $\begin{array}{l}\text { Home } \\
\text { language }\end{array}$ & $\begin{array}{l}\text { Social } \\
\text { class }\end{array}$ & Profession & $\begin{array}{l}\text { Strong } \\
\text { family ties }\end{array}$ & $\begin{array}{l}\text { Involved in } \\
\text { committed } \\
\text { relationship } \\
\text { (more than } \\
2 \text { years) }\end{array}$ \\
\hline 1 & Four & Honours degree in Communication & White & 28 & English & Upper & Personal Assistant & Yes & No \\
\hline 2 & Two & Honours degree in Marketing & White & 23 & English & Upper & Advertising consultant & Yes & Yes \\
\hline 3 & Three & Chartered Accountancy degree & White & 24 & English & Upper & Chartered Accountant & Yes & No \\
\hline 4 & Three & Medical degree & White & 24 & English & Upper & Doctor & Yes & No \\
\hline 5 & Three & Chartered Accountancy degree & White & 24 & English & Upper & Chartered Accountant & Yes & No \\
\hline 6 & Three & Chartered Accountancy degree & White & 24 & English & Upper & Chartered Accountant & Yes & Yes \\
\hline 7 & Four & Honours degree in Maths of Finance & White & 28 & English & Upper & Banker & Yes & Yes \\
\hline 8 & Five & Dietetics degree & White & 28 & English & Upper & Dietician & Yes & No \\
\hline 9 & Five & Nature Conservation degree & White & 26 & English & Upper & Nature Conservationist & Yes & No \\
\hline 10 & Two & Masters in Industrial Psychology & White & 25 & English & Upper & Industrial Psychologist & Yes & Yes \\
\hline
\end{tabular}

\section{Data gathering methods}

The methods of data gathering Franks used were twofold, namely, structured interviews ${ }^{10}$ and focus groups ${ }^{11}$. Franks conducted 6 individual interviews and one focus group which consisted of four participants.

Whilst constructing the interview guide Franks first brainstormed a list of possible questions that were related to the research topic. She put the questions in a logical order so that easier, less threatening questions were placed at the beginning of the conversation and more sensitive ones last. The questions she anticipated sparking discussion were: (i) How do you define your life roles at present? (ii) How do you define your life roles over the next ten years? (iii) What strategies do you anticipate to integrate your different life roles over the next ten years?

From the pilot interview it was clear that the first two questions provided the required reaction, but since the last one did not provide a comprehensive answer Franks felt it might have been too formal and therefore adjusted it as follows: How do you intend to integrate your multiple roles over the next ten years? Phrased in this way, relatively long and comprehensive answers were obtained from the participants. It allowed for more dialogue between the Franks and the participants. To the best of her ability Franks avoided asking leading questions.

Since it was impossible to take notes as well as listen to participants Franks tape recorded them. This allowed her to extract verbatim quotes from the transcriptions she made from the interviews which she uses in the article.

\section{Procedure}

All participants in any research have the right to know about the intent of the research project, as well as the right to privacy. Therefore Franks explained the purpose of the study to all the participants and assured them that their accounts would be kept confidential and would only be used for the study.

After the pilot interview to which we already referred to, Franks conducted two individual interviews by using the two original and the adjusted questions. She felt that the information obtained was comprehensive in terms of obtaining an answer to the research question and decided that it would be appropriate then to conduct a focus group, consisting of four participants, in order to compare the two different data gathering methods being used in the study and to acknowledge any inconsistencies. After the focus group was conducted Franks decided that structured individual interviews would provide a more comprehensive and meaningful account of the answers given by participants. This is because of the inherent dynamic of a group process, that is, that one person dominates the discussion, allows the possibility that responses may be influenced and some participants may fall silent in the discussion. Thus, Franks conducted four more structured individual interviews. Since we noted that the themes tended to reoccur in the participants' accounts we believed that the sample was saturated.

As mentioned previously, every individual interview, as well as the focus group, was tape-recorded to enable us to conduct the session in a consistent and efficient manner, to assist in data analysis, and to enhance the validity of the study. Detailed notes of every data gathering session were kept and relevant events and circumstances in each context were noted. For example, Franks wrote details of the location of each interview, who was involved, date and time of day, etc.

\section{Treatment of data}

There is an increasing tendency amongst contemporary qualitative researchers to apply computer-assisted data analysis software to facilitate the systematisation of the data. We chose not to use this technology to analyse the data. Our views agree with those of Esterberg (2002) who states that qualitative researchers work with texts, not numbers, and computers cannot "crunch" texts as easily as they can numbers. In addition, computer-assisted qualitative data analysis software promotes "an illusory order" in qualitative research. This implies that these programs have a built-in structure to code and build concepts, which in turn, create an illusory order since these do not arise from a careful study of patterns in the data and encourage data collection rather than creative thinking (Lindlof $\&$ Taylor, 2002).

We therefore decided to embark on grounded theory, without the assistance of computer software, to analyse the data. Esterberg (2002) suggests that the grounded theory approach can be used to work with data and develop meanings. We followed a constructivist grounded theory approach. This type of grounded theory, according to Locke (2001), recognises that the interviewer creates the data and ensuing analysis through interaction with the interviewee. Locke (2001) argues that data do not provide a window on reality. Rather, the "discovered" reality arises from the interactive process and its temporal, cultural, and structural contexts. The researcher and participants 
frame that interaction and confer meaning upon it. The researcher is part of what is viewed rather than separate from it. What a researcher sees shapes what he or she will define, measure and analyse (Locke, 2001).

On average, Franks yielded 4000 words per participant. She transcribed every interview fully i.e. every word of what the participants said was transcribed. Therefore the captured format of the data gathering produced a vast amount of data to be analysed. One procedure which is used in grounded theory to analyse such large amounts of data is known as coding. There are three types of such coding: open coding, axial coding and selective coding (see Pandit, 1996) ${ }^{12}$.

During the open coding stage, Franks worked intensively with the data, reading line after line, identifying themes and categories that seemed of interest. Then, out of the various codes which were created, she looked for recurring themes. She was careful to also note categories and themes that did not seem relevant to the research question. Denzin and Lincoln (2000) argue that, unlike quantitative research requiring data to fit into preconceived standardised codes, in grounded theory the researcher's interpretations of data shape his or her emergent categories. Franks did not have any preconceived ideas about what categories to expect or look for. She highlighted key phrases and words in the written transcript and then wrote categories in margins.

Whereas open coding fractures the data into concepts and categories, axial coding puts them back together in new ways by making connections between a category and its sub-categories (see Pandit, 1996). Thus, axial coding refers to the process of developing main categories and their sub-categories.

According to Pandit (1996), selective coding involves the integration of the categories that have been developed to form the initial theoretical framework. At this stage, Franks noted specific themes on the most frequently emerged categories. She also applied constant comparison in the data analysis phase whereby she compared data sets to one another as well as to the emerging theory.

Denzin and Lincoln (2000) state that memo writing is the intermediate step between coding and the first draft of the completed analysis ${ }^{13}$. Franks wrote detailed memos throughout the research process and she also constructed maps to allow herself to view how the various themes related to one another. Maps of the research participants' choices for their future were created so that we could understand the process of participants' decision-making more clearly. The identified themes overlapped with each other and Franks was able to depict relations between the themes.

In concluding this section, in order to analyse the vast amount of data Franks gathered from the participants, we made use of grounded theory, specifically using three analytical steps, namely, open coding, axial coding and selective coding. We therefore provided the participants with a voice in the study and obtained rich and substantive data.

\section{FINDINGS}

Out of the many findings that were extracted from the data, Franks managed to construct four major themes, namely: (i) the decision to pursue a career first and then a family, (ii) the decision to cut down on working hours in order to spend more time with children, (iii) the choice of whether or not to emigrate from South Africa thus leaving behind one's immediate family, and (iv) views on how society shapes expectations of women. These four themes are illustrated in Table 2 .

TABLE 2

\section{IDENTIFIED THEMES}

\begin{tabular}{|c|c|}
\hline THEME & QUOTE \\
\hline 1. Pursue career first and then family & $\begin{array}{l}\text { - "I'd like to make something of my career, I'd like to } \\
\text { build my career up" } \\
\text { - "I'd like to find someone to marry but I don't want to } \\
\text { get married too soon" } \\
\text { - "I find my career is a very big part of my life } \\
\text { right now" }\end{array}$ \\
\hline
\end{tabular}

2. Cut down on working hours to spend time with children

3. The choice to stay in South Africa

4. Expectations of women by society
- "When I have children perhaps that's when I'd like to open my own business so that I can work perhaps half day and at the same time spend quality time with my children"

- "If I get married and have kids I'd work either half day or have my own business or something from home"

- "What worries me is that I may not be in the same country as my parents, grandparents and sisters"

- "I'm a person with very strong family values so I think there's a heavy responsibility in keeping that family together and close knit. [I would do this] by staying in South Africa"

- "It sometimes irritates me the stereotype that the woman has to be the one to give up work. It's almost like our careers are less important, our aspirations are less important"

- I think that there's quite a lot of expectations and pressure on young women to either immediately succeed in their careers or to find someone and settle down and get married"

\section{CONSIDERATION}

Even though the ages of the participants ranged from 23 to 28 years old, all of them stated that in the next few years they would like to work and build up their careers. Eventually, though, they would like to get married and have children. However, their careers were currently their primary focus.

Most participants said that they would like to be at home full-time when they have infant children. Once the children go to nursery school, the main ideas brought forward were to work half day, part-time, flexitime, open one's own business at home, and even change one's career focus.

Some participants were considering emigrating from South Africa but were worried that they would not have a strong enough support system if they did, as well as not being able to play a strong familial role.

Some participants were of the opinion that society expects women to let their careers take a backseat when they have children and focus on their role as mother and wife. 
Figure 1 represents how three of the identified themes in this study are inter-related. Traditional views of society that women need to take care of their children play a fundamental role in their choice to delay marriage and childbearing and build up their careers first, and then to cut down on working hours to take care of their children. Similarly, building one's career first and delaying marriage may be a strategy to help women to be able to cut down on working hours once they have children.

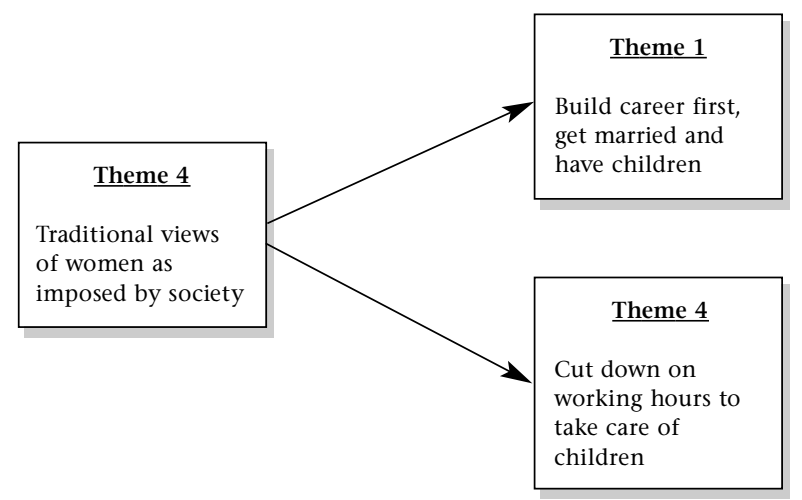

Figure 1: Relation of identified themes

\section{DISCUSSION}

\section{Theme 1: Build up career first and then get married and have children}

Participants were, at the time of data gathering, career-oriented and had decided to put marriage and childbearing on hold. This, finding confirms with Johnson and Mortimer's (2000) finding that young women are possibly delaying marriage to invest in their careers. These scholars (Johnson \& Mortimer, 2000) argue that in order to achieve both their family and their attainment goals, it may be that young women are shifting their attention to the timing of these pursuits; sequencing their investments in work and family as an alternative to choosing one over the other, or to pursuing them simultaneously. Therefore, young women today may be choosing to develop their careers first before they get married and have children so that they can prolong having to divide their time between the two domains for as long as possible in order to reduce the stress associated with role overload. This may be an effective strategy in the short-term but ultimately there will be losses for organisations that invest in their valuable female employees in the early career stage and then lose these employees due to family demands.

\section{Theme 2: Cutting down working hours when children are born}

Most participants wanted to cut down on working hours once they have children. They believed that they need to cut down the time they spend at work in order to increase the time they can spend with their children. This confirms the findings of a South African study conducted by Naidoo and Jano (2002), namely that even though dual-career women participate more in the work role, they have greater commitment to the home and family role than to the work role. Similarly, this finding confirms those of Cinamon and Rich (2002). These authors reported that women have higher work values than men but not higher work commitment. However, although their work values are higher, it may be difficult for these women to realise their work values fully because of their more extensive family obligations (Cinamon \& Rich, 2002). According to Cinamon and Rich (2002), many career women, including those who have nontraditional jobs and paid housekeeping help, continue to invest heavily in caring for their children and in tasks at home. These obligations may hinder the full development of work commitment that is commensurate with their high work values.

The issue of whether or not it is financially realistic to stop working full time when one's children are infants was acknowledged by many participants. The participants pointed out that they would start working again when their children are at school. However, none of them discussed exactly how long they believed they would not work. They merely suggested that they would go back to work once their children are at school. This may imply that they may not be working for up to ten years, depending on how many children they decide to have and the age gaps between their children. The families of these participants may therefore face financial burdens and constraints as a dual-income household is becoming more important due to the high cost of living in our country.

\section{Theme 3: Emigrating from South Africa}

Participants were aware of the importance of having a support structure, especially one that involves immediate family members. Those participants who were considering emigrating from South Africa were concerned about a loss of their support structure in South Africa, as well as playing a less prominent familial role to their immediate families. It seemed that family, to many of the participants, is a fundamental issue in the decision whether to emigrate from South Africa or not. Many participants stated that they were very close to their families and realised the importance of having a support system and maintaining their prominent familial roles. Some participants even suggested that they would like to play a strong mother role to their children as they enjoyed having had their own mothers present when they were young. None of the participants suggested that they would rely on external support functions, such as day care for infants or au pairs, while their children are infants.

\section{Theme 4: Prevalence of women's traditional views}

Most notably, the main finding of this study is that young women today still seem to hold traditional views of women in society even though they are striving to build a career. This finding supports the views of Hochschild in Lindsey (1997) that women work a 'second shift'. After a long day at work, women have to come home and work a second unpaid shift, that is, attend to family responsibilities. This finding also confirms that of Phillips and Imhoff's (1997) stating that women appear to place increased importance on goals in the work domain. However, this change has not detracted from the importance women give to the home and family domain. Therefore women may today experience more role overload and stress, which in turn, may have negative consequences for them, their families, as well as the organisation in which they are employed.

Theme 4 therefore relates highly with Themes 1 and 2. That is, participants want to build up their career as much as possible in the early career stage because once they have children they believe they will have to cut down on their working hours by changing their working patterns or even their occupation since they have a strong pull towards their traditional role of mother. However, contradictions are also present amongst these interrelated themes. All participants wanted to cut down on working hours when they have children although many wanted to maintain their independence and not have to rely on anyone for financial support. Therefore the traditional role of a man being the breadwinner, as perceived by young, career-oriented women, cannot be confirmed by this study.

Three of the identified themes relate strongly with the point made above by Nelson and Burke (2002) that women are prone to role overload and stress due to their limited resources. This comparison is evident because, in these three themes, strategies such as part-time work were suggested that would help minimise role overload and stress. In theme 1 and theme 2, women wanted to build their careers first and then get married and have children and cut down on working hours once they have children. Therefore women may wish to employ a strategy to minimise time-based conflict. Theme 3 stated that women may not want to emigrate from South Africa because they would lose their support system, thereby implying a loss of a strategy to reduce role overload. 
Particularly interesting is that the thoughts of the participants were mainly engaged in how they will integrate their work and family roles once they have children. None of them gave input as to how they would take care of elderly relatives, assume the duties of a wife, or participate in any other life roles. It seems that these young women underestimate the importance of integrating life roles other than that of mother, or do not have enough experience to make informed decisions about different life roles in their future. Not only does a woman need to employ a prominent role for her children, but also for her husband and family, as well as for herself.

Overall, the study confirms the viewpoints of Lindsey (1997) that women may combine work and marriage successfully, but are severely compromised in their quest for career ascendance by marital and family obligations. The pull toward the wife and mother role is so great that many women, possibly even most, will not abdicate what they see as their primary responsibility, even if it means giving up career opportunities. Home-based businesses, part-time work, and employment offering flexible work time are compromises women use to balance their roles.

Is the study useful and its findings sound? While at times we felt frustrated with the amount of uncertainty we experienced during the grounded theory phase (edginess and impatience) and was anxious as to what themes might emerge from the data, we gained valuable insight into these women's realities. Their experiences and views on the topic certainly gave Franks a clear understanding of her own reality, being a young, career-oriented woman in current South Africa.

As far as the soundness of the study is concerned, we believe that it is of reasonable good quality. We can obviously not provide a comprehensive account of how the study meets the appropriate criteria here. Therefore the following very brief outline will suffice. We are convinced that we properly applied all the strategies which are generally regarded important when it comes to judging a qualitative study. More particularly, (i) both research participants ${ }^{14}$ and colleagues found our discussion of the research and interpretation of the findings credible ${ }^{15}$, 16 ; we applied peer debriefing17, (besides Franks' immediate study leader, she offered a draft of this article to a colleague who has recently completed a $\mathrm{PhD}$ dissertation using a modernist qualitative methodology, who provided valuable ideas which we incorporated), (iii) we exercised strict personal discipline by examining our own personal biases at each stage in the research process particularly since Franks has similar socio-demographics (e.g. race, gender and marital status) as the research participants which may have influenced the way in which she executed the research ${ }^{18}$, and (iv) by managing to a offer a 'thick description', i.e. rich account of the views of this particular group of women and consequently indicating the extend of transferability ${ }^{19}$ of this study's findings to other milieu.

In summary, to the best of Franks' ability, her role in the research process was to interact with the research participants in a natural, unobtrusive and non-threatening manner to gather rich data from them so that she can add knowledge to the field of the work-family domain, and not to pass judgement on the setting.

\section{Recommendations}

Recognising the unity of women's work and personal lives is an important strategic adaptation for any organisation. If a woman's desired goals for balancing her work and non-work roles are achieved, she will most likely be a productive employee who experiences less stress, as well as better job satisfaction and quality of life. Instead of losing valuable employees and having to develop new talent, industrial psychologists should help organisations identify the role conflicts of female employees. They can then find a balance between the individual and the organisation, benefiting both parties.

Young women and teenaged girls should choose career paths and formulate career goals by knowing which work-family options are most convenient for them. It is therefore essential that schools, tertiary institutions and industrial psychologists play a fundamental role in efficient career planning. Emphasis should be placed on the importance of different life roles and how to integrate them through the different stages of one's life, as well as the strategies that are available for women and families to integrate their multiple life roles. Another topic of importance is planning how to take care of young children as well as one's family, husband, self and other life roles. By realistically assessing the time and energy needed to fulfill multiple life roles, young women can be better prepared to make strategic decisions about their careers and effectively solve problems when faced with the conflicting demands of work and home in the future.

Organisations should be able to clarify what options are available to young working women so that these women can realistically plan for their future. Desired options could include all the strategies suggested by the research participants when they have children, such as part-time work, half day or flexitime. Another example is job sharing which is an effective way of cutting down working hours for employees but still enabling employees to complete tasks efficiently to benefit the organisation. Furthermore, on-site child care facilities could be offered so that working hours need not decrease. By knowing what options best suit a woman's lifestyle, employers could, during the recruitment process, promote an appropriate work-family balance policy. Employers could also describe policies with regard to parental leave and other family-related policies during the selection and orientation phases. By following an appropriate work-family balance policy, employers can reduce low morale amongst their workforce, as well as absenteeism and turnover.

In addition to providing support for familial roles, organisations should also help women in the workplace to integrate their various other life roles. For example, by offering gym facilities on site organisations could aid in time management by minimising commuting to gym thereby assisting women to integrate a recreational role into their lives.

Finally, pre-marital counselors can help dual-career couples acknowledge that the role of one's spouse may be undermined. If a woman or man does not appreciate his or her partner and devote quality time to them, marital problems may occur.

Conflict is a part of life. There is no way to completely avoid it but it is important to note that positive planning can reduce stress for women and the organisations for which they work.

\section{Suggestions for further research}

Pressures from the work and family domains have different influences on diverse groups of people, depending on the importance they attribute to life roles. Women of different ages, races, social classes, etc. will differ in their choices of integrating work and family roles. The sample used in this study was restricted to a specific age group, social class, race, education level, number of years of work experience, and marital status. This study therefore has certain shortcomings such as that its findings cannot be applied to other women of different demographics. In addition, the majority of the research participants shared close ties with their families. Results may have proved different if the sample did not have strong family values. Therefore, research in the domain of work and family can 
benefit from gaining knowledge and insight into the views of different types of women, in different career and life stages, on how they view and plan to integrate their multiple life roles. This includes exploring the views of young women from different age groups, races and social classes, as well as older, career-oriented women who are married and/or have children.

It could also prove to be valuable if further research were to be conducted on how young men anticipate multiple life role planning. It would also be interesting to explore society's views on men and whether or not these views are consistent with traditional views of men as the breadwinner.

Furthermore, research conducted in the future could focus on young women in specific occupations and/or industries as the research participants of this study had different occupations.

Lastly, it would be worthwhile to explore why young women want to build up their careers if they intend cutting down their work hours or changing the scope of their careers when they have children.

We truly hope that the insights gained and recommendations made in the study will help women of all ages to understand and appreciate all the different life roles in which they engage and help them find a balance between these life roles because it unquestionably did for Franks.

In conclusion, we would like to reiterate that much research has been done in the field of work and family life. In the introductory part of this article we explained such research, such as the scientific meaning of life roles as well as the consequences of occupying different life roles. In light of all of the above findings and recommendations, we hold a humble belief that this study has contributed to enabling the scientific community to understand and appreciate the social construction of this particular sample's reality of life roles. We feel that this study has particularly added some qualitative insight by articulating that even young, career-oriented women in our modern society still hold traditional views of women as a mother and homemaker. Finally, we feel that a need has been created to investigate the social construction of life roles of our diverse nation thereby aiming to create a nationwide quality of life.

\section{REFERENCES}

Aaron-Corbin, C. (1999). The multiple role balancing act Management Review, 88 (9), 62.

Barnett, R. C. (1999). A new work-life model for the twenty-first century. The Annals of the American Academy of Political and Social Science, 562 (10), 143-158.

Brink, B. \& de la Rey, C. (2001). Work-family interaction strain: coping strategies used by successful women in the public, corporate and self-employed sectors of the economy. Journal of Psychology, 31 (4), 55-61.

Bryman, A. (2004). Social research methods. (2nd ed.). Oxford, NY: Oxford University Press.

Cinamon, R. G. \& Rich, Y. (2002). Gender differences in the importance of work and family roles: implications for workfamily conflict. Sex Roles, 47 (11), 531-542.

Collins, J. L. (1996). A cross-cultural study of the meaning of working and life roles in South African youth. Unpublished master's dissertation, Rand Afrikaans University: Johannesburg.

Daymon, C. \& Holloway, I. (2002). Qualitative research and marketing communications. London: Routledge.

Denzin, N. K. \& Lincoln, Y. S. (2000). Handbook of qualitative research. ( $2^{\text {nd }}$ ed.). Thousand Oaks, CA: Sage.

Denzin, N.K., \& Lincoln, Y.S. (2003). The Landscape of Qualitative Research: Theories and Issues. $2^{\text {nd }}$ ed. London: Sage.

Esterberg, K. (2002). Qualitative methods in social research. Boston: McGraw-Hill.

Gottlieb, B. H., Kelloway, E. K. \& Barham, E. (1998). Flexible work arrangements: managing the work-family boundary. Chichester, UK: John Wiley \& Sons.
Greenhaus, J. H., Callanan, G. A. \& Godshalk, V. M. (2000). Career management. ( $3^{\text {rd }}$ ed.). Orlando, FL: Harcourt.

Han, S. K. \& Moen, P. (1999). Work and family overtime: a life course approach. The Annals of the American Academy Political and Social Science, 562 (6), 98-110.

Johnson, M. K. \& Mortimer, J. T. (2000). Work-family orientations and attainments in the early life course. Thousand Oaks, CA: Sage.

Kerlinger, F. N. \& Lee, H. B. (2000). Foundations of behavioural research (4th ed.). Fort Worth, TX: Harcourt.

Krause, A. E. (2003). Work-family balance: the relationship between employment type, work-family conflict and life satisfaction in women. Unpublished master's dissertation, University of the Witwatersrand: Johannesburg.

Kruger, S. (1999). The balancing of life roles as essential condition for personal leadership. Unpublished master's dissertation, Rand Afrikaans University: Johannesburg.

Lindlof, T. R. \& Taylor, B. C. (2002). Qualitative communication research methods. ( $2^{\text {nd }}$ ed.). Thousand Oaks, CA: Sage.

Lindsey, L. L. (1997). Gender roles: a sociological perspective. (3 ${ }^{\text {rd }}$ ed.). Upper Saddle River, NJ: Prentice Hall.

Litosseliti, L. (2003). Using focus groups in research, London: Continuum.

Locke, K. (2001). Grounded theory in management research. Thousand Oaks, CA: Sage.

Muchinsky, P. M., Kriek, H. J. \& Schreuder, A. M. G. (1998). Personnel psychology. (2nd ed.). South Africa: International Thomson Publishing.

Naidoo, A. V. \& Jano, R. (2002). Role salience of dual-career women managers. SA Journal of Industrial Psychology, 28 (3), 69-74.

Nelson, D. L. \& Burke, R. S. (2002). Gender, work stress and health. Washington, DC: American Psychological Association.

Noor, N. M. (2004). Work-family conflict, work- and family-role salience, and women's well-being The Journal of Social Psychology, 144 (4), 389-405.

Pandit, N. R. (1996). The creation of theory: a recent application of the grounded theory approach. The Qualitative Report, 2 (4), http://www.nova.edu/ssss/QR/QR2-4/pandit.html.

Phillips, S. D. \& Imhoff, A. R. (1997). Women and career development: a decade of research. Annual Review of Psychology, 48, http://www.questia.com.

Reskin, B. \& Padavic, I. (1994). Women and men at work. Thousand Oaks, CA: Pine Forge.

Rothbard, N. P. \& Edwards, J. R. (2003). Investment in work and family roles: a test of identity and utilitarian motives. Personnel Psychology, 56 (3), 699.

Ruderman, M. N., Ohlott, P. J., Panzer, K. \& King, S. N. (2002). Benefits of multiple roles for managerial women. Academy of Management Journal, 45 (2), 369.

Schurink, W. J. (2003). Special edition. Qualitative research in management and organisational studies with reference to recent South African research. SA Journal of Human Resource Management, 1 (3):2-14.

Schurink, W. J. (2005). Lecture thirteen. Evaluating qualitative research. In W.J. Schurink. Qualitative research: introducing key features of an interpretive approach to social science research. Doctoral Programme: Leadership in Performance and Change. Department of Human Resource Management UJ, Johannesburg. Oct. 2005.

Sharma, S. (1999). Multiple-role and women's health: a multilinear model. Equal Opportunities International, 18 (8), 16-24.

Smit, R. (2001). Work-family spillover revisited: is there hope for marital happiness in the dual-earner family? Koers: Bulletin for Christian Scholarship, 66 (4), 603-620.

Theunissen, B., Van Vuuren, L. J. \& Visser, J. D. (2003). Communication of job-related information and work-family conflict in dual-career couples. Journal of Industrial Psychology, 29 (1), 18-25.

Wadron, I., Weiss, C. C. \& Hughes, M. E. (1998). Interacting effects of multiple roles on women's health. Journal of Health and Social Behaviour, 39 (3), 216-237. 